\title{
Upaya meningkatkan prestasi belajar pendidikan agama Islam dengan menerapkan model pembelajaran pakem pada siswa
}

\author{
Amrisal Amrisal ${ }^{*}$ \\ Sekolah Menengah Pertama Negeri 4 Ranah Pesisir
}

\begin{tabular}{l} 
Article Info \\
\hline Article history: \\
Received Jun $12^{\text {th }}, 2021$ \\
Revised Jul $20^{\text {th }}, 2021$ \\
Accepted Aug $26^{\text {th }}, 2021$ \\
\hline
\end{tabular}

\section{Keyword:}

Pendidikan Agama Islam Pakem

\begin{abstract}
Keberhasilan proses belajar mengajar di dalam kelas sangat ditentukan oleh strategi pembelajaran, bagaimanapun lengkap dan jelasnya komponen lain, tanpa diimplementasikan melalui strategi yang tepat, maka komponenkomponen tersebut tidak akan memiliki makna dalam proses pencapaian tujuan. Oleh karena itu setiap akan mengajar guru diharuskan untuk menerapkan strategi atau metode tertentu dalam pelaksanaan pembelajaran. Penelitian ini menggunakan penelitian tindakan (action research) sebanyak tiga putaran. Setiap putaran terdiri dari empat tahap yaitu: rancangan, kegiatan dan pengamatan, refleksi, dan refisi. Sasaran penelitian ini adalah siswa Kelas VII 3. Dari hasil analis didapatkan bahwa prestasi belajar siswa mengalami peningkatan dari siklus I sampai siklus III yaitu, siklus I $(68,00 \%)$, siklus II $(80,00 \%)$, siklus III $(92,00 \%)$. Simpulan dari penelitian ini adalah model pembelajaran PAKEM dapat berpengaruh positif terhadap motivasi belajar siswa Kelas VII 3, serta model pembelajaran ini dapat digunakan sebagai salah satu alternatif pembelajaran PAI.
\end{abstract}

(C) 2021 The Authors. Published by IICET.

This is an open access article under the CC BY-NC-SA license (https://creativecommons.org/licenses/by-nc-sa/4.0

\section{Corresponding Author:}

Amrisal Amrisal,

Sekolah Menengah Pertama Negeri 4 Ranah Pesisir

Email: amrizal@gmail.com

\section{Pendahuluan}

Dalam mengajar, guru harus pandai menggunakan pendekatan secara arif dan bijaksana, bukan sembarangan yang bisa merugikan anak didik. Pandangan guru terhadap anak didik akan menentukan sikap dan perbuatan. Setiap guru tidak selalu mempunyai pandangan yang sama dalam menilai anak didik. Hal ini akan mempengaruhi pendekatan yang guru ambil dalam pengajaran.

Guru yang memandang anak didik sebagai pribadi yang berbeda dengan anak didik lainnya akan berbeda dengan guru yang memandang anak didik sebagai makhluk yang sama dan tidak ada perbedaan dalam segala hal. Maka adalah penting meluruskan pandangan yang keliru dalam menilai anak didik. Sebaiknya guru memandang anak didik sebagai individu dengan segala perbedaannya, sehingga mudah melakukan pendekatan dalam pengajaran.

Pada dasarnya dalam kehidupan suatu bangsa, faktor pendidikan mempunyai peranan yang sangat penting untuk menjamin perkembangan dan kelangsungan hidup bangsa tersebut. Secara langsung maupun tidak langsung pendidikan adalah suatu usaha sadar dalam menyiapkan pertumbuhan dan perkembangan anak melalui kegiatan, bimbingan, pengajaran dan pelatihan bagi kehidupan dimasa yang akan datang. Tentunya hal ini merupakan tanggung jawab bersama antara pemerintah, anggota masyarakat dan orang tua. Untuk mencapai keberhasilan ini perlu dukungan dan partisipasi aktif yang bersifat terus menerus dari semua pihak. 
Berhasilnya tujuan pembelajaran ditentukan oleh banyak faktor diantaranya adalah faktor guru dalam melaksanakan proses belajar mengajar, karena guru secara langsung dapat mempengaruhi, membina dan meningkatkan kecerdasan serta keterampilan siswa. Untuk mengatasi permasalahan di atas dan guna mencapai tujuan pendidikan secara maksimal, peran guru sangat penting dan diharapkan guru mampu menyampaikan semua mata pelajaran yang tercantum dalam proses pembelajaran secara tepat dan sesuai dengan konsep-konsep mata pelajaran yang akan disampaikan.

Dengan menyadari kenyataan tersebut di atas, maka dalam penelitian ini penulis mengambil judul "Upaya Meningkatkan Prestasi Belajar Pendidikan Agama Islam Dengan Menerapkan Model Pembelajaran PAKEM Pada Siswa Kelas VII 3 UPT SMPN 4 Ranah Pesisir Kabupaten Pesisir Selatan Tahun Pelajaran 2020-2021"

\section{Metode}

Sesuai dengan jenis penelitian yang dipilih, yaitu penelitian tindakan, maka penelitian ini menggunakan model penelitian tindakan dari Kemmis dan Taggart (dalam Arikunto, Suharsimi, 2002:83), yaitu berbentuk spiral dari siklus yang satu ke siklus yang berikutnya. Setiap siklus meliputi planning (rencana), action (tindakan), observation (pengamatan), dan reflection (refleksi). Langkah pada siklus berikutnya adalah perencanaan yang sudah direvisi, tindakan, pengamatan, dan refleksi. Sebelum masuk pada siklus I dilakukan tindakan pendahuluan yang berupa identifikasi permasalahan. Siklus spiral dari tahap-tahap penelitian tindakan kelas dapat dilihat pada narasi berikut.

1. Rancangan/rencana awal, sebelum mengadakan penelitian peneliti menyusun rumusan masalah, tujuan dan membuat rencana tindakan, termasuk di dalamnya instrumen penelitian dan perangkat pembelajaran.

2. Kegiatan dan pengamatan, meliputi tindakan yang dilakukan oleh peneliti sebagai upaya membangun pemahaman konsep siswa serta mengamati hasil atau dampak dari diterapkannya pengajaran kontekstual model pengajaran berbasis masalah.

3. Refleksi, peneliti mengkaji, melihat dan mempertimbangkan hasil atau dampak dari tindakan yang dilakukan berdasarkan lembar pengamatan yang diisi oleh pengamat.

4. Rancangan/rencana yang direvisi, berdasarkan hasil refleksi dari pengamat membuat rancangan yang direvisi untuk dilaksanakan pada siklus berikutnya.

Observasi dibagi dalam tiga siklus, yaitu siklus 1, 2, dan seterusnya, dimana masing siklus dikenai perlakuan yang sama (alur kegiatan yang sama) dan membahas satu sub pokok bahasan yang diakhiri dengan tes formatif di akhir masing putaran. Siklus ini berkelanjutan dan akan dihentikan jika sesuai dengan kebutuhan dan dirasa sudah cukup. Tempat penelitian di Kelas VII 3 UPT SMPN 4 Ranah Pesisir Kabupaten Pesisir Selatan, waktu penelitian dilaksanakan pada bulan Maret sampai dengan bulan Mei 2021. Subyek penelitian adalah siswa-siswi kelas IV tahun pelajaran 2020-2021 pada pokok bahasan kisah Nabi Ibrahim a.s, dan Nabi Ismail a.s.

Alat pengumpul data dalam penelitian ini adalah tes buatan guru yang fungsinya adalah: (1) untuk menentukan seberapa baik siswa telah menguasai bahan pelajaran yang diberikan dalam waktu tertentu, (2) untuk menentukan apakah suatu tujuan telah tercapai, dan (3) untuk memperoleh suatu nilai (Arikunto, Suharsimi, 2002:149). Sedangkan tujuan dari tes adalah untuk mengetahui ketuntasan belajar siswa secara individual maupun secara klasikal. Di samping itu untuk mengetahui letak kesalahan-kesalahan yang dilakukan siswa sehingga dapat dilihat dimana kelemahannya, khususnya pada bagian mana TPK yang belum tercapai. Untuk memperkuat data yang dikumpulkan maka juga digunakan metode observasi (pengamatan) yang dilakukan oleh teman sejawat untuk mengetahui dan merekam aktivitas guru dan siswa dalam proses belajar mengajar.

Dalam rangka menyusun dan mengolah data yang terkumpul sehingga dapat menghasilkan suatu kesimpulan yang dapat dipertanggungjawabkan, maka digunakan analisis data kuantitatif dan pada metode observasi digunakan data kualitatif. Cara penghitungan untuk mengetahui ketuntasan belajar siswa dalam proses belajar mengajar sebagai berikut.

1. Merekapitulasi hasil tes

2. Menghitung jumlah skor yang tercapai dan prosentasenya untuk masing-masing siswa dengan menggunakan rumus ketuntasan belajar seperti yang terdapat dalam buku petunjuk teknis penilaian yaitu siswa dikatakan tuntas secara individual jika mendapatkan nilai minimal 65, sedangkan secara klasikal dikatakan tuntas belajar jika jumlah siswa yang tuntas secara individu mencapai $85 \%$ yang telah mencapai daya serap lebih dari sama dengan $65 \%$.

3. Menganalisa hasil observasi yang dilakukan oleh guru sendiri selama kegiatan belajar mengajar berlangsung. 


\section{Hasil dan Pembahasan}

\section{Hubungan Pembelajaran Model PAKEM dengan Ketuntasan Belajar}

1. Siklus I

a. Tahap Perencanaan

Pada tahap ini peneliti mempersiapkan perangkat pembelajaran yang terdiri dari rencana pelajaran 1, soal tes formatif 1 dan alat-alat pengajaran yang mendukung. Selain itu juga dipersiapkan lembar observasi pengelolaan model pembelajaran PAKEM, dan lembar observasi aktivitas guru dan siswa.

b. Tahap Kegiatan dan Pelaksanaan

Pelaksanaan kegiatan belajar mengajar untuk siklus I dilaksanakan pada tanggal 4 Maret 2019 di Kelas VII 3 jumlah siswa 22 siswa. Dalam hal ini peneliti bertindak sebagai pengajar. Adapun proses belajar mengajar mengacu pada rencana pelajaran yang telah dipersiapkan. Pengamatan (observasi) dilaksanakan bersamaan dengan pelaksanaan belajar mengajar.

Pada akhir proses belajar mengajar siswa diberi tes formatif I dengan tujuan untuk mengetahui tingkat keberhasilan siswa dalam proses belajar mengajar yang telah dilakukan. Adapun data hasil penelitian pada siklus I adalah sebagai berikut.

Tabel 1. Rekapitulasi Hasil Tes Formatif Siswa Pada Siklus I

\begin{tabular}{clc}
\hline Nomor & \multicolumn{1}{c}{ Uraian } & Hasil Siklus I \\
1. & Nilai rata-rata tes formatif & 70,00 \\
2. & Jumlah siswa yang tuntas belajar & 15 \\
& Persentase ketuntasan belajar & 68,18 \\
\hline
\end{tabular}

Dari tabel di atas dapat dijelaskan bahwa dengan menerapkan pembelajaran model PAKEM diperoleh nilai rata-rata prestasi belajar siswa adalah 70,00 dan ketuntasan belajar mencapai $68,18 \%$ atau ada 15 siswa dari 22 siswa sudah tuntas belajar. Hasil tersebut menunjukkan bahwa pada siklus pertama secara klasikal siswa belum tuntas belajar, karena siswa yang memperoleh nilai $\geq 65$ hanya sebesar $68,18 \%$ lebih kecil dari persentase ketuntasan yang dikehendaki yaitu sebesar $85 \%$. Hal ini disebabkan karena siswa masih merasa baru dan belum mengerti apa yang dimaksudkan dan digunakan guru dengan menerapkan pembelajaran

c. Refleksi. Dalam pelaksanaan kegiatan belajar mengajar diperoleh informasi dari hasil pengamatan sebagai berikut:

1) Guru kurang maksimal dalam memotivasi siswa dan dalam menyampaikan tujuan pembelajaran

2) Guru kurang maksimal dalam pengelolaan waktu

3) Siswa kurang aktif selama pembelajaran berlangsung

d. Refisi

Pelaksanaan kegiatan belajar mengajar pada siklus I ini masih terdapat kekurangan, sehingga perlu adanya revisi untuk dilakukan pada siklus berikutnya.

1) Guru perlu lebih terampil dalam memotivasi siswa dan lebih jelas dalam menyampaikan tujuan pembelajaran. Dimana siswa diajak untuk terlibat langsung dalam setiap kegiatan yang akan dilakukan.

2) Guru perlu mendistribusikan waktu secara baik dengan menambahkan informasi-informasi yang dirasa perlu dan memberi catatan.

3) Guru harus lebih terampil dan bersemangat dalam memotivasi siswa sehingga siswa bisa lebih antusias.

2. Siklus II

a. Tahap perencanaan

Pada tahap ini peneliti mempersiapkan perangkat pembelajaran yang terdiri dari rencana pelajaran 2, soal tes formatif 2 dan alat-alat pengajaran yang mendukung. 
b. Tahap kegiatan dan pelaksanaan

Pelaksanaan kegiatan belajar mengajar untuk siklus II dilaksanakan pada tanggal 11 Maret 2021 di Kelas VII 3 dengan jumlah siswa 22 siswa. Dalam hal ini peneliti bertindak sebagai pengajar. Adapun proses belajar mengajar mengacu pada rencana pelajaran dengan memperhatikan revisi pada siklus I, sehingga kesalahan atau kekurangan pada siklus I tidak terulang lagi pada siklus II. Pengamatan (observasi) dilaksanakan bersamaan dengan pelaksanaan belajar mengajar.

Pada akhir proses belajar mengajar siswa diberi tes formatif II dengan tujuan untuk mengetahui tingkat keberhasilan siswa dalam proses belajar mengajar yang telah dilakukan. Instrumen yang digunakan adalah tes formatif II. Adapun data hasil penelitian pada siklus II adalah sebagai berikut.

Tabel 2. Rekapitulasi Hasil Tes Formatif Siswa Pada Siklus II

\begin{tabular}{clc}
\hline $\begin{array}{c}\text { Nomor } \\
1 .\end{array}$ & Nilai rata-rata tes formatif & Uasil Siklus II \\
& 77,73 \\
2. & Jumlah siswa yang tuntas belajar & 17 \\
3. & Persentase ketuntasan belajar & 79,01 \\
\hline
\end{tabular}

Dari tabel di atas diperoleh nilai rata-rata prestasi belajar siswa adalah 77,73 dan ketuntasan belajar mencapai $79,01 \%$ atau ada 17 siswa dari 22 siswa sudah tuntas belajar. Hasil ini menunjukkan bahwa pada siklus II ini ketuntasan belajar secara klasikal telah mengalami peningkatan sedikit lebih baik dari siklus I. Adanya peningkatan hasil belajar siswa ini karena setelah guru menginformasikan bahwa setiap akhir pelajaran akan selalu diadakan tes sehingga pada pertemuan berikutnya siswa lebih termotivasi untuk belajar. Selain itu siswa juga sudah mulai mengerti apa yang dimaksudkan dan diinginkan guru dengan menerapkan pembelajaran model PAKEM.

c. Refleksi

Dalam pelaksanaan kegiatan belajar diperoleh informasi dari hasil pengamatan sebagai berikut.

1) Memotivasi siswa

2) Membimbing siswa merumuskan kesimpulan/menemukan konsep

3) Pengelolaan waktu

d. Revisi Rancangan

Pelaksanaan kegiatan belajar pada siklus II ini masih terdapat kekurangan-kekurangan. Maka perlu adanya revisi untuk dilaksanakan pada siklus II antara lain:

1. Guru dalam memotivasi siswa hendaknya dapat membuat siswa lebih termotivasi selama proses belajar mengajar berlangsung.

2. Guru harus lebih dekat dengan siswa sehingga tidak ada perasaan takut dalam diri siswa baik untuk mengemukakan pendapat atau bertanya.

3. Guru harus lebih sabar dalam membimbing siswa merumuskan kesimpulan/menemukan konsep.

4. Guru harus mendistribusikan waktu secara baik sehingga kegiatan pembelajaran dapat berjalan sesuai dengan yang diharapkan.

5. Guru sebaiknya menambah lebih banyak contoh soal dan memberi soal-soal latihan pada siswa untuk dikerjakan pada setiap kegiatan belajar mengajar.

3. Siklus III

a. Tahap perencanaan

Pada tahap ini peneliti mempersiapkan perangkat pembelajaran yang terdiri dari rencana pelajaran 3 , soal tes formatif 3 dan alat-alat pengajaran yang mendukung.

b. Tahap kegiatan dan pengamatan

Pelaksanaan kegiatan belajar mengajar untuk siklus III dilaksanakan pada tanggal 18 Mei 2021 di Kelas VII 3 dengan jumlah siswa 22 siswa. Dalam hal ini peneliti bertindak sebagai pengajar. Adapun proses belajar mengajar mengacu pada rencana pelajaran dengan memperhatikan revisi pada siklus II, sehingga kesalahan atau kekurangan pada siklus II tidak terulang lagi pada siklus III. Pengamatan (observasi) dilaksanakan bersamaan dengan pelaksanaan belajar mengajar.

Pada akhir proses belajar mengajar siswa diberi tes formatif III dengan tujuan untuk mengetahui tingkat keberhasilan siswa dalam proses belajar mengajar yang telah dilakukan. Instrumen yang digunakan adalah tes formatif III. Adapun data hasil penelitian pada siklus III adalah sebagai berikut. 
Tabel 3. Hasil Formatif Siswa Pada Siklus III

\begin{tabular}{clc}
\hline $\begin{array}{c}\text { Nomor } \\
1 .\end{array}$ & Nilai rata-rata tes formatif & Uasil Siklus III \\
& 82,73 \\
2. & Jumlah siswa yang tuntas belajar & 19 \\
3. & Persentase ketuntasan belajar & 83,36 \\
\hline
\end{tabular}

Berdasarkan tabel di atas diperoleh nilai rata-rata tes formatif sebesar 82,73 dan dari 22 siswa telah tuntas sebanyak 19 siswa dan 3 siswa belum mencapai ketuntasan belajar. Maka secara klasikal ketuntasan belajar yang telah tercapai sebesar $86,36 \%$ (termasuk kategori tuntas). Hasil pada siklus III ini mengalami peningkatan lebih baik dari siklus II. Adanya peningkatan hasil belajar pada siklus III ini dipengaruhi oleh adanya peningkatan kemampuan guru dalam menerapkan pembelajaran model PAKEM sehingga siswa menjadi lebih terbiasa dengan pembelajaran seperti ini sehingga siswa lebih mudah dalam memahami materi yang telah diberikan.

c. Refleksi

Pada tahap ini akan dikaji apa yang telah terlaksana dengan baik maupun yang masih kurang baik dalam proses belajar mengajar dengan penerapan pembelajaran model PAKEM. Dari data-data yang telah diperoleh dapat diuraikan sebagai berikut:

1) Selama proses belajar mengajar guru telah melaksanakan semua pembelajaran dengan baik. Meskipun ada beberapa aspek yang belum sempurna, tetapi persentase pelaksanaannya untuk masing-masing aspek cukup besar.

2) Berdasarkan data hasil pengamatan diketahui bahwa siswa aktif selama proses belajar berlangsung.

3) Kekurangan pada siklus-siklus sebelumnya sudah mengalami perbaikan dan peningkatan sehingga menjadi lebih baik.

4) Hasil belajar siswa pada siklus III mencapai ketuntasan.

d. Revisi Pelaksanaan

Pada siklus III guru telah menerapkan pembelajaran model PAKEM dengan baik dan dilihat dari aktivitas siswa serta hasil belajar siswa pelaksanaan proses belajar mengajar sudah berjalan dengan baik. Maka tidak diperlukan revisi terlalu banyak, tetapi yang perlu diperhatikan untuk tindakan selanjutnya adalah memaksimalkan dan mempertahankan apa yang telah ada dengan tujuan agar pada pelaksanaan proses belajar mengajar selanjutnya penerapan model pembelajaran PAKEM dapat meningkatkan proses belajar mengajar sehingga tujuan pembelajaran dapat tercapai.

1) Ketuntasan Hasil Belajar Siswa

Melalui hasil penelitian ini menunjukkan bahwa pembelajaran model PAKEM memiliki dampak positif dalam meningkatkan prestasi belajar siswa. Hal ini dapat dilihat dari semakin mantapnya pemahaman siswa terhadap materi yang disampaikan guru (ketuntasan belajar meningkat dari siklus I, II, dan III) yaitu masing-masing 68,18\%, 79,01\%, dan 86,36\%. Pada siklus III ketuntasan belajar siswa secara klasikal telah tercapai.

2) Kemampuan Guru dalam Mengelola Pembelajaran

Berdasarkan analisis data, diperoleh aktivitas siswa dalam proses belajar mengajar dengan menerapkan model pembelajaran PAKEM dalam setiap siklus mengalami peningkatan. Hal ini berdampak positif terhadap prestasi belajar siswa yaitu dapat ditunjukkan dengan meningkatnya nilai rata-rata siswa pad setiap siklus yang terus mengalami peningkatan.

3) Aktivitas Siswa Dalam Pembelajaran

Berdasarkan analisis data, diperoleh aktivitas siswa dalam proses pembelajaran PAI pada pokok bahasan kisah nabi Ibrahim a.s, dan nabi Ismail a.s dengan model pembelajaran PAKEM yang paling dominan adalah, mendengarkan/memperhatikan penjelasan guru, dan diskusi antar siswa/antara siswa dengan guru. Jadi dapat dikatakan bahwa aktivitas siswa dapat dikategorikan aktif.

Sedangkan untuk aktivitas guru selama pembelajaran telah melaksanakan langkah-langkah kegiatan belajar mengajar dengan menerapkan pengajaran konstekstual model pengajaran berbasis masalah dengan baik. Hal ini terlihat dari aktivitas guru yang muncul di antaranya aktivitas membimbing dan mengamati siswa dalam menemukan konsep, menjelaskan materi yang sulit, memberi umpan balik/evaluasi/tanya jawab dimana prosentase untuk aktivitas di atas cukup besar. 


\section{Simpulan}

Berdasarkan hasil penelitian yang telah dipaparkan selama tiga siklus, hasil seluruh pembahasan serta analisis yang telah dilakukan dapat disimpulkan sebagai berikut: 1) Model pembelajaran PAKEM dapat meningkatkan kualitas pembelajaran PAI; 2) Pembelajaran model PAKEM memiliki dampak positif dalam meningkatkan prestasi belajar siswa yang ditandai dengan peningkatan ketuntasan belajar siswa dalam setiap siklus, yaitu siklus I (68,18\%), siklus II (79,01\%), siklus III (86,36\%); 3) Model pembelajaran PAKEM dapat menjadikan siswa merasa dirinya mendapat perhatian dan kesempatan untuk menyampaikan pendapat, gagasan, ide dan pertanyaan; 4) Siswa dapat bekerja secara mandiri maupun kelompok, serta mampu mempertanggungjawabkan segala tugas individu maupun kelompok; 5) Penerapan pembelajaran model PAKEM mempunyai pengaruh positif, yaitu dapat meningkatkan motivasi belajar siswa

\section{Referensi}

Ali, Muhammad. (1996). Guru Dalam Proses Belajar Mengajar. Bandung: Sinar Baru Algesindon. Arikunto, Suharsimi. (1993). Manajemen Mengajar Secara Manusiawi. Jakarta: Rineksa Cipta.

Arikunto, Suharsimi. (2001). Dasar-dasar Evaluasi Pendidikan. Jakarta: Bumi Aksara.

Arikunto, Suharsimi. (2002). Prosedur Penelitian Suatu Pendekatan Praktek. Jakarta: Rineksa Cipta.

Azhar, Lalu Muhammad. (1993). Proses Belajar Mengajar Pendidikan. Jakarta: Usaha Nasional.

Daroeso, Bambang. (1989). Dasar dan Konsep Pendidikan Moral Pancasila. Semarang: Aneka Ilmu.

Djamarah, Syaiful Bahri. (2002). Strategi Belajar Mengajar. Jakarta: Rineksa Cipta.

Djamarah, Syaiful Bahri. (2002). Psikologi Belajar. Jakarta: Rineksa Cipta.

Hadi, Sutrisno. (1982). Metodologi Research, Jilid 1. Yogyakarta: YP. Fak. Psikologi UGM.

Hamalik, Oemar. (2002). Psikologi Belajar dan Mengajar. Bandung: Sinar Baru Algesindo.

Hasibuan K.K. dan Moerdjiono. (1998). Proses Belajar Mengajar. Bandung: Remaja Rosdakarya.

Margono. (1997). Metodologi Penelitian Pendidikan. Jakarta. Rineksa Cipta.

Masriyah. (1999). Analisis Butir Tes. Surabaya: Universitas Press.

Ngalim, Purwanto M. (1990). Psikologi Pendidikan. Bandung: PT. Remaja Rosdakarya.

Nur, Moh. 2001. Pemotivasian Siswa untuk Belajar. Surabaya: University Press. Univesitas Negeri Surabaya.

Rustiyah, N.K. (1991). Strategi Belajar Mengajar. Jakarta: Bina Aksara.

Sardiman, A.M. (1996). Interaksi dan Motivasi Belajar Mengajar. Jakarta: Bina Aksara.

Soekamto, Toeti. (1997). Teori Belajar dan Model Pembelajaran. Jakarta: PAU-PPAI, Universitas Terbuka.

Sukidin, dkk. (2002). Manajemen Penelitian Tindakan Kelas. Surabaya: Insan Cendekia.

Surakhmad, Winarno. (1990). Metode Pengajaran Nasional. Bandung: Jemmars.

Suryosubroto, B. (1997). Proses Belajar Mengajar di Sekolah. Jakarta: PT. Rineksa Cipta.

Syah, Muhibbin. (1995). Psikologi Pendidikan, Suatu Pendekatan Baru. Bandung: Remaja Rosdakarya.

Usman, Moh. Uzer. (2001). Menjadi Guru Profesional. Bandung: Remaja Rosdakarya. 